\title{
Cultivating successful student farms through site selection and design
}

\author{
Rebekah VanWieren * \\ Montana State University
}

Submitted June 12, 2018 / Revised August 7 and 30, 2018 / Accepted August 30, 2018 /

Published online November 15, 2018

Citation: VanWieren, R. (2018). Cultivating successful student farms through site selection and design. Journal of A griculture, Food Systems, and Community D evelopment, 8(3), 187-205.

https:/ / doi.org/ 10.5304/ jafscd.2018.083.013

Copyright ( 2018 by the Author. Published by the Lyson Center for Civic Agriculture and Food Systems. Open access under CC BY license.

\begin{abstract}
The number of college and university student farms is growing rapidly in the United States. New, and even established, student farms have the opportunity and challenge to define both their strategy and physical design, which are critical to the farm's success. In this exploratory study of student farms across the U.S., I examine the spatial and physical design relationships that tend to be hallmarks of thriving university student farms. I employ grounded theory and content analysis to analyze 27 semistructured interviews with student farm personnel and direct field observations from 19 student farm sites at 12 public universities. The findings of this study suggest important considerations for site selection based on accessibility, appearance, and visibility. Onsite design recommendations for layout, spaces, and features are presented for six domains of the farm site. These findings illuminate how resilient student farm sites
\end{abstract}

\footnotetext{
* Rebekah VanWieren, Plant Sciences and Plant Pathology D epartment, Montana State University; 311 Leon Johnson Hall; Bozeman, Montana 59715 USA; +1-406-994-7539; rebekah.vanwieren@montana.edu
}

rely not only on appropriate biophysical conditions and production efficiencies, but also on physical spaces that stimulate social interaction and align with the broader campus context. These insights are most applicable to new or expanding student farms undergoing the master planning process.

\section{Keywords}

Campus Planning, Community Building, Student Farms, Education, Farm Vision, Landscape D esign, Resiliency, Site D esign, Site Selection

\section{Introduction and Literature Review}

Student farms have rapidly grown at colleges and universities across the United States, and for good reason: they are meaningful and significant places where students, staff, faculty, and community members gather to engage in and learn about sustainable food systems (Leis, Whittington, Bennett, \& K leinhenz, 2011; Parr \& Trexler, 2011; Sayre \&

\section{Funding Disclosure}

This work was supported in part by U.S. D epartment of Agriculture National Institute of Food and Agriculture Hatch Project 1015767. 
Clark, 2011). More specifically, student farms benefit universities and local communities by supporting food systems education and research (Biernbaum, Ngouajio, \& Thorp, 2006; LaCharite, 2016; Markhart, 2006; Parr \& Horn, 2006), experiential learning opportunities (Carlson, 2008; Parr \& Trexler, 2011), broader community health and outreach, and valuable green infrastructure on campus (Biembaum et al., 2006; Carlson, 2008; Hyslop, 2015; Leis et al., 2011; Markhart, 2006; Parr \& Horn, 2006; Parr \& Trexler, 2011).

Planning for and building a successful university student farm is a challenging and laborious undertaking involving multiple stakeholders and long-term planning. G rowing a student farm involves strategizing about mission and goals, property development, curriculum integration, staffing and student involvement, production systems, marketing, and outreach programs. It also requires significant commitments to funding and staffing (Ratasky et al., 2015), support from administrators and academic departments (Leis et al., 2011), and ongoing coordination with campus planners and facilities management. These unique dimensions of student farms situated in campus environments create similarly unique conditions for site selection and physical design that should be considered in the farm's development.

There is a small but growing domain of scholarship on university student farm planning. This research has primarily focused on farm administration, production systems, educational programming, and student experiences (Biernbaum, 2006; LaCharite, 2016; Parr \& Horn, 2006; Parr \& Trexler, 2011). These studies highlight the importance of student farms for providing experiential learning spaces beyond the classroom, particularly as agriculture educators strive to engage students from a variety of disciplines who are less likely to possess practical farming skills. Several case studies have examined the historical development and operations of well-regarded student farm programs in the United States (Ashling, T chida, Markhart, \& Porter, 2007; Biernbaum et al., 2006; Clark, 2014; Parr \& Horn, 2006; Sayre \& Clark, 2011), emphasizing the value of administrative and curricular systems accompanying farm site development.

Scholars have recently begun to directly investigate success factors for university student farms. Leis and colleagues (2011) discovered that the two most difficult challenges of operating student farms were working with limited budgets and gaining support from administration. Ratasky and colleagues (2015) expanded this area of inquiry, undertaking a detailed examination of student farm success factors that also included some spatial or physical factors. For example, a key insight from this study was that student farm success depends on the stability of a permanent farm site, or "land tenure." This is because, without secure land holdings, farms are unlikely to invest in building and soil improvements if the location is competing with long-range building plans and other development pressures (Ratasky et al., 2015). This study also found that a clear farm vision and long-term plan is important for managing a successful farm (Ratasky et al., 2015). Long-term plans, or master plans, help develop a farm's mission and goals, which should also inform site selection and design (Milburn \& Vail, 2010). Also recently, Hyslop (2015) valuably compiled student farm maps and imagery as part of a guidebook of 10 student farms in the U.S., with the aim of providing comparative overviews of farm histories, site information, and associated university courses; but, this study did not examine the value of spatial characteristics in particular. While this growing area of study has generated vital insights into successful student farms and related educational programs, there remains limited scholarship on the physical planning and onsite design features of student farms.

Beyond the literature specifically focused on university student farms, some landscape architecture scholarship on the history, planning, and design of food spaces is informative for the present study. For example, studies of community gardens (e.g., Lawson, 2005; Milburn \& Vail, 2010) and farmers markets (e.g., Francis \& G riffith, 2011) find that social spaces foster human engagement that builds interaction and community. Furthermore, Milburn and Vail (2010) outline pragmatic strategies for community garden planning, site selection, site layout, and site elements. Their study provides insights on the importance of access to biophysical elements (e.g., sun exposure, water, soil), equipment circulation, and storage. Philips' 
(2013) studies of urban agriculture and edible landscapes highlight planning for city-scale food systems as well as developing a site-scale project using an integrated systems approach; but, her studies only include one university farm case. Finally, the City of Vancouver's Urban Agriculture $\mathrm{G}$ arden $\mathrm{G}$ uide (G ocova, n.d.) provides substantial site layout and design details and drawings, but does not incorporate the student experience or university campus planning setting. Still, limited research attention has been given to the physical design of edible landscapes within the college or university context.

To address these gaps in the literature, the present study examines how the physical and spatial design aspects of university student farms contribute to farm success. The goal of this inquiry is to explore how the organization, qualities, and relationships among the farm's physical features-location, visibility, size, layout, structures, and furnishings - affect the site's functionality and user experience. This study contributes to the literature on student farms in three ways. First, it articulates practical physical design strategies for creating a university student farm, based on an analysis of exemplary student farms around the United States. This is valuable because it broadens the type of information for building a successful student farm. Second, the study articulates how campus location and the use of surrounding land impact the physical design and management of student farms. Third, it highlights how the design of student farm spaces benefits user engagement and communitybuilding. These contributions are beneficial to new or expanding student farms that are developing a farm vision and site plan.

\section{Methods}

Study Sites

To build an understanding of successful site selection and design of university student farms, I

Figure 1. College and University Student Farm Sample Geographic Distribution

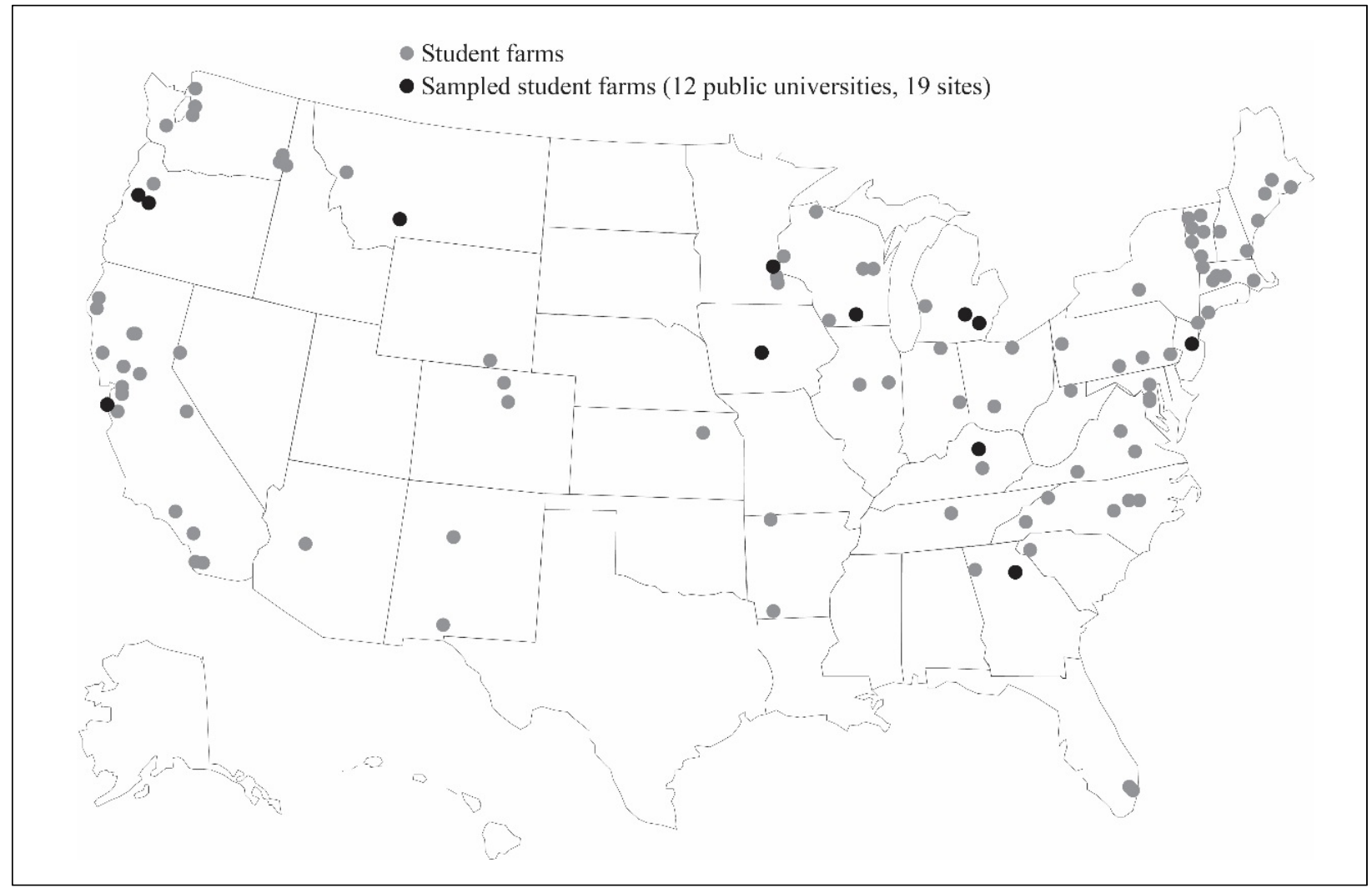

Sources: Sayre \& Clark, 2011; Sustainable Agriculture Education Association, 2016. 
visited 19 exemplary student farms sites at 12 public universities around the U.S. (see Figure 1). I chose student farms to sample based on varied geographic distribution and land use context, recommendations from student farm leaders, highlighted cases in Sayre and Clark (2011), and student farm lists from the Sustainable Agricultural Education Association (2016). I utilized a purposive sampling method that sufficiently led to theoretical saturation related to my research question (D eming \& Swaffield, 2011).
College and university student farms are highly diverse in their missions, strategies, and design characteristics. They are differentiated from other agricultural projects by both "student initiative or possibilities for student leadership at the farm" and "a degree of attention and concern paid to questions of environmental stewardship and sustainability" (Sayre \& Clark, 2011, p. 6). Table 1 categorizes the student farms I studied according to predominant features related to land planning and site design. The farms ranged in size

Table 1. Student Farm Sample Characteristics

\begin{tabular}{|c|c|c|c|c|c|c|}
\hline University & Student Farm Project & $\begin{array}{l}\text { Farm Size } \\
\quad(\mathrm{ac})\end{array}$ & $\begin{array}{l}\text { Land Use } \\
\text { Contexta }\end{array}$ & $\begin{array}{l}\text { Campus } \\
\text { Location }\end{array}$ & $\begin{array}{l}\text { Distance to } \\
\text { Campus } \\
\text { Center (mi) } \\
\end{array}$ & $\begin{array}{l}\text { Farm } \\
\text { Stage }\end{array}$ \\
\hline \multirow[t]{2}{*}{ Iowa State University } & Student Organic Farm & 2 & Agricultural & Off-campus & 9.5 & Sustained \\
\hline & $\begin{array}{l}\text { Campus Garden run by } \\
\text { Student Organic Farm }\end{array}$ & $<0.5$ & Campus & On campus & $<0.25$ & Developing \\
\hline \multirow{2}{*}{$\begin{array}{l}\text { Michigan State } \\
\text { University }\end{array}$} & Student Organic Farm & 15 & Agricultural & Off campus & 5 & Sustained \\
\hline & $\begin{array}{l}\text { Liberty Hyde Bailey } \\
\text { Urban Farm }\end{array}$ & $<0.5$ & Campus & On campus & 0.25 & Established \\
\hline $\begin{array}{l}\text { Montana State } \\
\text { University }\end{array}$ & Towne's Harvest Garden & 3 & Agricultural & Off-campus & 1.5 & Sustained \\
\hline \multirow[t]{2}{*}{ Oregon State University } & $\begin{array}{l}\text { Organic Growers Club } \\
\text { Farm }\end{array}$ & 1.5 & Agricultural & Off-campus & 3 & Sustained \\
\hline & $\begin{array}{l}\text { Oak Creek Center for } \\
\text { Urban Horticulture farm } \\
\text { site }\end{array}$ & 6.5 & Mixed use & Campus edge & 1 & Sustained \\
\hline Rutgers University & $\begin{array}{l}\text { Student Farm, Rutgers } \\
\text { Gardens }\end{array}$ & $<0.5$ & Park & Off campus & 3.5 & Developing \\
\hline \multirow[t]{2}{*}{$\begin{array}{l}\text { University of California, } \\
\text { Santa Cruz }\end{array}$} & $\begin{array}{l}\text { Student Farm, Center for } \\
\text { Agroecology \& Sustain- } \\
\text { able Food Systems }\end{array}$ & 27 & Agricultural & Off-campus & 1.25 & Sustained \\
\hline & Alan Chadwick Garden & 2 & Campus & On campus & 0.25 & Sustained \\
\hline University of Georgia & UGArden & 6.5 & Agricultural & Off-campus & 4 & Established \\
\hline University of Kentucky & Student Organic Farm & 18 & Agricultural & Off-campus & 5.25 & Sustained \\
\hline \multirow[t]{2}{*}{ University of Michigan } & $\begin{array}{l}\text { Student Farm, Matthaei } \\
\text { Botanical Gardens }\end{array}$ & 1 & Park & Off-campus & 6 & Established \\
\hline & Project Grow Garden & $<0.5$ & Mixed use & Campus edge & 0.5 & Sustained \\
\hline University of Minnesota & $\begin{array}{l}\text { Cornercopia, Student } \\
\text { Organic Farm }\end{array}$ & 5.5 & Agriculture & Campus edge & 0.5 & Sustained \\
\hline \multirow[t]{2}{*}{ University of Oregon } & The Urban Farm & 1.5 & Mixed Use, Park & Campus edge & 0.5 & Sustained \\
\hline & $\begin{array}{l}\text { Neighborhood Garden } \\
\text { Site }\end{array}$ & 0.5 & Mixed Use & Off-campus & 0.5 & Developing \\
\hline \multirow{2}{*}{$\begin{array}{l}\text { University of Wisconsin, } \\
\text { Madison }\end{array}$} & F.H. King Student Farm & 1.75 & Park & Off-campus & 2.5 & Sustained \\
\hline & $\begin{array}{l}\text { Pyle Center Rooftop } \\
\text { Garden }\end{array}$ & $<0.5$ & Campus & On campus & 0 & Developing \\
\hline
\end{tabular}

a Measured using Google Earth Pro and AutoCAD software; rounded to nearest quarter acre ( $0.1 \mathrm{ha})$ or quarter mile $(0.4 \mathrm{~km})$.

b Farm stage was defined as: developing, 0-4 years old; established, 5- 9 years; sustained, $10+$ years. 
from 1,400 ft² $\left(130 \mathrm{~m}^{2}\right)$ to over 25 acres (10.1 ha). I made field observations to categorize primary land uses surrounding the farm site as either campus, agriculture, park or public green spaces, and mixed-use, which may include a combination of residential, commercial, campus, and other uses. The campus setting of the farms ranged from being adjacent to central campus buildings or residence halls, which I defined as "on" campus, to being located within larger agricultural research properties or park-like settings (such as arboretums or botanical gardens), which I defined as "off" campus. There were also four projects located within transitions between campus buildings and mixed-use or neighborhood land uses, which I defined as a "campus edge" setting. The farms in the study also varied from being located less than 0.25 miles $(0.40 \mathrm{~km})$ to nearly 10 miles $(16 \mathrm{~km})$ from the center of campus or a student union building. Finally, I characterized the farm stage, or age, to better understand interviewee data and farm site histories, but data collection and analysis did not significantly differentiate among farm stages.

D ata Collection I collected two primary types of data for analysis: semistructured interviews and direct observations. Because my research questions were exploratory and there is little existing design research within the university student farm context, inductive field research was an ideal fit (Creswell, 2014). The qualitative interview format coupled with onsite observations allowed for more dynamic and spatially-genuine sources of data for elaborating findings (D eming \& Swaffield, 2011). I recorded 27 semistructured interviews with farm leaders and participants at the student farms in question. The role of the interviewees were farm managers (41\%), faculty $(22 \%)$, or other students or volunteers closely involved with the farm (37\%). I interviewed a farm manager at all but one university. Forty-one percent of the interviews represented productionfocused student farms, $26 \%$ represented demonstration-focused student farms, and 33\% represented both production- and demonstrationfocused farm sites. I conducted the interviews either at the student farm while walking or sitting in the shade, or in faculty offices, and I recorded them for transcription. On average, interviews were 37 minutes each, for a total of 993 minutes of recorded content. I began by asking initial questions about the interviewees' roles and responsibilities and the farm type. I then asked specific questions that explored farm functionality and important spatial features for operations, favorite and most memorable places, least favorite places and unsuccessful features or projects, ideas for improving the farm space or site elements they had changed to increase farm functionality, and farm interests. When needed, I asked interviewees follow-up questions to expand on content related to the research questions.

I also collected data through direct observation at each student farm while farm personnel went about their work. My observations and field notes were conducted as a nonparticipant observer, since I was an outsider and non-expert at the student farms. O nsite activities at each university lasted at least one day, totaling approximately 71 hours of formal observation. Activities included a formal farm tour, informal conversations with farm workers, photographic documentation, and sketches. These observations contributed to a more comprehensive understanding of the farm processes and spatial experience. Further mapping and geospatial data were also collected using Google Earth Pro and AutoCAD software.

A nalysis

I used a grounded theory approach to data analysis in which I iteratively moved between the collected data and emerging insights on design characteristics of successful farms (Glaser \& Strauss, 1967). The analysis process occurred over a period of four months. I first free-coded, line by line, each interview transcript using NVivo 11 software for themes that seemed recurrent, central, or meaningful and were directly related to my research question (Boyatzis, 1998). Further recoding was conducted by exploring patterns in the coded data across interviews to create higherorder categories of emergent themes. From the direct observation data, I analyzed site diagrams of the existing farm spaces for site organization of circulation and spaces. I also explored onsite 
photographs in tandem to evolving patterns in the interview data to understand materials, aesthetic quality of, or uses of space. I went through multiple iterations of this analytic process until I reached theoretical saturation with the data (Glaser \& Strauss, 1967).

\section{Findings and Discussion}

D ata analysis revealed two domains of physical design - site selection and onsite features - that emerged as crucial for the successful design of university student farms. First, I found three key considerations to be related to successful site selection: accessibility, appearance, and visibility. Second, I found six key elements, characterized as farm domains, to be related to the successful design of onsite spaces and features: the hub, gathering areas, experimental areas, compost areas, attractions, and reflective areas. Together, these patterns provide a conceptual framework for how the physical design and management of student farms can facilitate food production as well as educational and social functions to ensure longevity within the campus landscape. In the following sections, I describe and elaborate on each of these patterns.

\section{Site Selection Considerations}

The following three patterns illustrate physical considerations for the successful selection of sites for university student farms. Note that this study did not focus on the biophysical needs- sun exposure, water, soil quality, topography, land area, etc. - that are also essential to comprehensive site analysis.

\section{A coessibility}

The first site selection pattern that emerged in the data was how the site's campus location impacted accessibility to needed resources. Accessibility considerations for site selection tended to manifest in two realms, each with their own trade-offs: peoplerelated or facilities-related. Accessibility for people to travel to the farm from campus was the most prominent theme among these. Human accessibility matters for farms because most student farms rely on students and volunteers to operate the farm, even when a full-time manager is on staff. The farm's physical relationship to campus is therefore extremely valuable. Having safe and efficient transportation was especially challenging for farms further from central campus and for those relying on students who are less likely to own automobiles (e.g., freshmen and sophomores). O ne farm director described this challenge, stating, "By the time you put a student in a van or a car and you drive 'em out there, the focus gets lost. Some students don't show up. It's really hard for them to go back and maintain [the farm]" (F8). ${ }^{1} \mathrm{O}$ ne student leader went so far as to say, "I also wish that this was on campus so people would actually walk past it. I think the engagement level would be higher because I mean physical access to this place is really hard for individuals because there's not a bus route here" (F5).

Conversely, on-campus farms benefited greatly from easy and efficient access. Easy access helped to foster engagement and more effectively demonstrated connections between food and social systems on campus, which are important aspects of many student farm missions. A director of an urban student farm adjacent to a residence hall discussed this accessibility benefit, saying that, "They go out and hang out and there's just this great therapy in being able to go right outside your dorm and engage with it" (F4).

Accessibility to facilities and materials is also important for student farms. While off-campus student farms tend to have greater acreage, and therefore more resources, on-campus student farm sites tended to lack access to the same breadth of resources, such as greenhouses, storage, soil, compost, or loading areas preferred for daily farm work. This creates obstacles for tasks like truck access for compost delivery or food packaging and distribution. O ne student manager noted that, "having to rely on other structures or other areas for what we need is a time sink and a little frustrating when we don't have what we need or don't have the space to get what we need" (F4). Another farm director noted that, "We're going to get our own greenhouse

\footnotetext{
${ }^{1}$ Participant quotes are cited by their corresponding student farm $(\mathrm{F})$ in chronological order of site visits (\#).
} 
that we can have space and do stuff in and not have to shuffle around and negotiate and share" (F8).

\section{A ppearance}

The second site selection pattern that emerged in the data was that the farm site's appearance should align with its campus landscape context. Traditional campus landscapes are characterized by turf areas, deciduous trees, and ornamental planting beds. Similarly, conventional agricultural landscapes strive to be tidy and organized. Set within either of these contexts, production practices at student farms were often perceived as messy, weedy, and unkempt. Like Nassauer's (1995) seminal landscape architecture research on using "cues to care" to frame messy native landscapes in the context of manicured settings, student farms applied maintenance cues, elements of beauty, and organization to frame the farm sites in order to build acceptance.

The appearance pattern and resultant aesthetic expectations manifested simultaneously as a nuisance and necessity. Meeting appearance expectations was a nuisance when they curtailed work on food production or when extra maintenance was not anticipated. For example, one farm director noted, "the problem with the ones that have to look a certain way is you gotta have serious student commitment to make it happen. It can't be just like piecemealed together" (F9). In some cases where these nuisances were a threat to farm operations, farm sites selected locations with more aesthetic flexibility. The advantage of doing so was the ability to experiment with farm spaces and production methods without the pressures of matching with surrounding appearance norms. O ne faculty director expressed,

I think there's an attitude by some of the campus planners who think that the campus farms are a little messy and they're a little unwilling to give up some of the decisionmaking to students, whereas we've [university botanical gardens] been very open to allowing students to shape the spaces themselves and trying to accommodate their needs. (F5)
Similarly, one student farm moved from a location along a major arterial street because "if we have a field that gets really, really weedy it's not like everyone driving by is going to see it [the weeds]" (farm manager, F1).

At the same time, participants consistently recognized the importance of the farm's appearance and saw aesthetics as a necessity to show commitment and appeal for visitors and decisionmakers (Sayre \& Clark, 2011, p. 328). For example, one faculty director shared, "A esthetics is, in my mind, a competency when you think about sustainability. I think if you don't understand what a beautiful world looks like, how can you sustain it?" (F4). A ppearance was important for gaining buy-in from campus grounds and facilities management as well. O ne farm manager noted, "If we're making it pretty, they [campus planners] don't care" (F10). Appearance was also important for attracting visitors, especially in settings where farms were not a typical land use. A student manager said, "Just trying to get someone in there, you know, who has never done it before; Y ou have to appeal to people's aesthetic, wants, and needs to be able to do that" (F4). A nother student manager at a project located in central campus shared,

Anything to do with aesthetics you really have to think about because it's so apparent to many people that usually don't see these types of things, gardens and such in the city. So, you really have to have these appearances. It can't just be overrun or unkempt. Y ou have to really focus on that. (F3)

Interestingly, in the case of a new satellite site associated with the University of O regon Urban Farm, the student farm itself became the "cue to care" in the context of repurposing a universityowned vacant lot. The conversion of the lot to a student farm took an underutilized, "unframed" space and created a neighborhood asset. The student farm acted as a landscape buffer where, as the farm manager noted, "the university planning department is really concerned about encroaching on the neighborhoods surrounding the university" (F10). 
V isibility

The third site selection pattern that emerged in the data was that the farm site's location impacted its visibility (i.e., how well it can be seen, or its prominence in the landscape). Visibility is important for navigating to and within the site, attracting people to explore the site, and facilitating the farm's demonstration goals. For some farm sites, high visibility was a benefit. For example, visibility of on-campus farms helped garner the interest of student workers and enticed people passing by to engage with the site. O ne student leader noted,

They're [the residence hall and student farm site] here together purposefully, and that plays together to create this community of students and other students that get drawn to it. I just love seeing that dynamic relationship happen, because people are drawn to the area and then they're drawn to these other places because of that. So, I think that's my favorite part and that's the part I think is the most important, the holistic picture of it. (F4)

Farms located within campus tended to value visibility for giving the site an open feeling. One farm manager said, "Over at the Columbia site, you'll notice that it's a lot more spread out, and there's grassy spaces that seem to be serving no purpose, but the purpose is that it's more inviting to people" (F10). Also, farms intentionally chose sites with high visibility as an opportunity for specialized research in food systems for highlydeveloped settings. One faculty director shared how visibility was a benefit, saying,

Urban food production's not at all like rural food production. It's very, very different and it comes with all the challenges of being in a densely populated area. So for us, the challenges are very real-world challenges that we're trying to get answered for our stakeholders across the country, literally. And the one that we're facing right now is the bees.
Oh my G od, we had no idea how many people are fearful of bees. This is a farm, but it's not a farm. It's a campus. It's a res hall. It's the same challenges that people who live in high-density housing in urban settings are gonna face. (F4)

On the other hand, visibility also created difficulties that tended to manifest in one of two ways. First, locations with greater visibility require heightened security measures that restrict the farm's outreach and demonstration programming. For example, student farms with rooftop growing spaces were required to keep them locked unless a student leader was present, precluding access for students and visitors to informally walk through the site, read signage, and explore what was going on during other rooftop events. This defeated the purpose of choosing a a highly visible site for the project. Second, visibility led to unexpected visitors, which some farms narrated as a deterrent. O ne farm staff member expressed, "I do want people to go in it, but I guess I want them there when we can engage them in an organized way, rather than a random way" (F5). A nother faculty advisor shared a concern about research projects, saying, "I like the idea of signage as long as it doesn't attract people to walk through it. I mean, they shouldn't be clomping through" (F1).

D esign Considerations for Six Site D omains The following six site domains ${ }^{2}-$ the hub, gathering areas, attractions, student projects, compost, and reflective places- emerged as key areas and features of successful university student farms. The following description of each domain provides onsite design considerations for circulation, spaces, structures, and detailed features, as well as their benefit for farm functionality.

D omain 1: The $\mathrm{H} \mathrm{ub}$

Fundamental to a successful student farm design is a command center or central hub (see Figure 2). Whether composed of a simple outdoor area, its own building, or several buildings, hubs function as

2 There were also patterns in the data related to animal systems, but because only two of the farms I visited had animals, the data was not sufficient to analyze. 
Figure 2. Farm Hubs: Large (Left), Medium (Center), Small (Right)
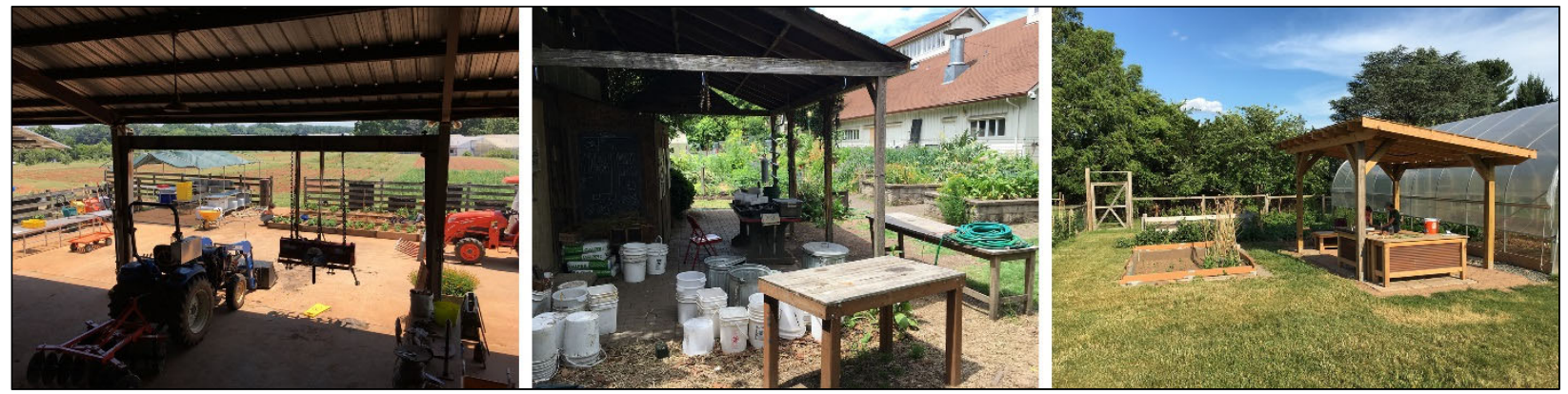

the primary node where the work day starts and ends. The farm hub acts as a site landmark and orienting feature that one manager described as "key because it's a central location where you can tell people to meet you" (F8). Especially given varied staff schedules and high numbers of volunteers, the farm hub was consistently identified as a key feature for farm efficiency and productivity because it centralized farm management spaces. The physical design of well-established farm hubs serves four key functions: site organization, circulation, administration, and storage. While the hub serves as a point of informal gathering and socializing due to its primary functions, formal gathering areas are distinct features of successful student farms that may or may not be incorporated within the hub area (see D omain 2).

\section{Site Organization}

First, farm hubs help organize the layout of other farm spaces. This impact on site organization tended to manifest in two ways: spatial hierarchy and legibility. Here, spatial hierarchy means that spaces requiring more attention were placed closest to the farm hub--e.g., demonstration projects, production areas that use hand-scale methods, or areas vital to farm operations like season extension structures or multi-purpose buildings. Conversely, spaces that required less attention or used larger equipment, including areas for mechanized production, or were everchanging, like student projects, were placed further from the farm hub. This site organization was important because it saved time moving materials and tools between the farm hub and work areas. To design a site that accommodates this spatial hierarchy, the farm hub does not necessarily have to be in the geographic center of the farm site, but rather should be located with easy access to and from key areas. However, for a site that is long and linear, the spatial hierarchy will be more efficient if the farm hub is placed near the center of the site.

L egibility means that farms clearly delineated spaces, paths, and boundaries in a manner such that "as people come there, they can understand how things are laid out" (F5). Successful legibility was structured to be visible from the farm hub. This aspect of site organization helped facilitate work for students and volunteers, many of whom had no farming or gardening experience. For example, one respondent described having uniform and repeated spaces as "universally understandable for students" and "more accessible to volunteers" (student, F8). Another farm manager noted that, "pathways are really big, because I think people get nervous about where to step and where not to step if they don't know anything about it" (F9). Clearly delineated growing spaces, or zones, also helped to disperse large groups- in one case over 100 students during class time- - in a more systematic manner. This also helped "people know what they can do in their free time" (F10) by having a designated work zone for which they can take ownership during the semester. Finally, clearly delineating site boundaries with permanent fencing was a successful strategy to not only protect farm resources in areas with deer but also to stake claim to farm spaces and provide farm legitimacy.

\section{Farm Flow}

Second, farm hubs aid physical circulation, or "farm flow" as I refer to it, for sequencing food 
production processes. This was achieved by ensuring easy connectivity that links growing spaces to washing stations or processing facilities, which connects to storing or packing, and finally connects to loading and distribution. A farm staff member described this farm flow design, saying,

We have an awesome packing shed next to the field that has clean water and a place for that water to go, even though it's just into the ground. Thinking about that system of when you harvest [is important]: Where do you bring the food? What do you do with it? How do you clean it? Then having a road that goes right there so we can drive the truck up and load all the boxes. (F12)

D esigned farm flow was especially important for production-oriented farms that had organic certification or where food safety protocols were carefully followed. For example, a student manager said, "O ur packing shed is close to the roadway where we can pull up the wagon and enter through the back of the shed. The flow of moving from the field where its dirty to the cooler on the other side, of having it flow from dirty to clean, that's really good" (F9).

\section{A dministration}

Third, farm hubs facilitate administrative activities related to the student farm. The farm hub acts as the primary location for all communication. This is important for managing the spatiotemporal challenges of having work tasks, staff, and volunteers dispersed throughout the site and work week. In addition, the integration of spaces for both farm operations and administration at the hub allows farm staff to keep working while waiting for visitors, groups, or community supported agriculture (CSA) members to arrive at the farm. The administrative-related physical features that tended to be incorporated at successful student farms were vehicle parking, bike racks, offices or meeting rooms, scheduling and task boards, staff lockers, kitchens, bathrooms, and farm bells. Successful farms that did not incorporate each of these features at the farm hub tended to at least have access to these resources within adjacent facilities or grounds.

\section{Storage}

Forth, farm hubs provide storage space for equipment, tools, materials, and produce. At successful farms, storage spaces tend to be permanent, a combination of covered and uncovered areas, and integrated with administrative or social spaces. More covered storage, in general, was the type of structure that developing and established student farms needed most (see Figure 3).

Locating primary storage areas at the central hub is important for three key reasons: consolidation, organization, and socialization. First, having all equipment and tools in a designated, centralized area increased work efficiency by guaranteeing availability and access. For example, one student worker noted, "It's nice that the tools are around here. Everything is pretty accessible. I like that it's
Figure 3. Season Extension Structure Converted to Needed Covered Storage (Left); Systematic Organization of Tools at Farm Hub (Right)

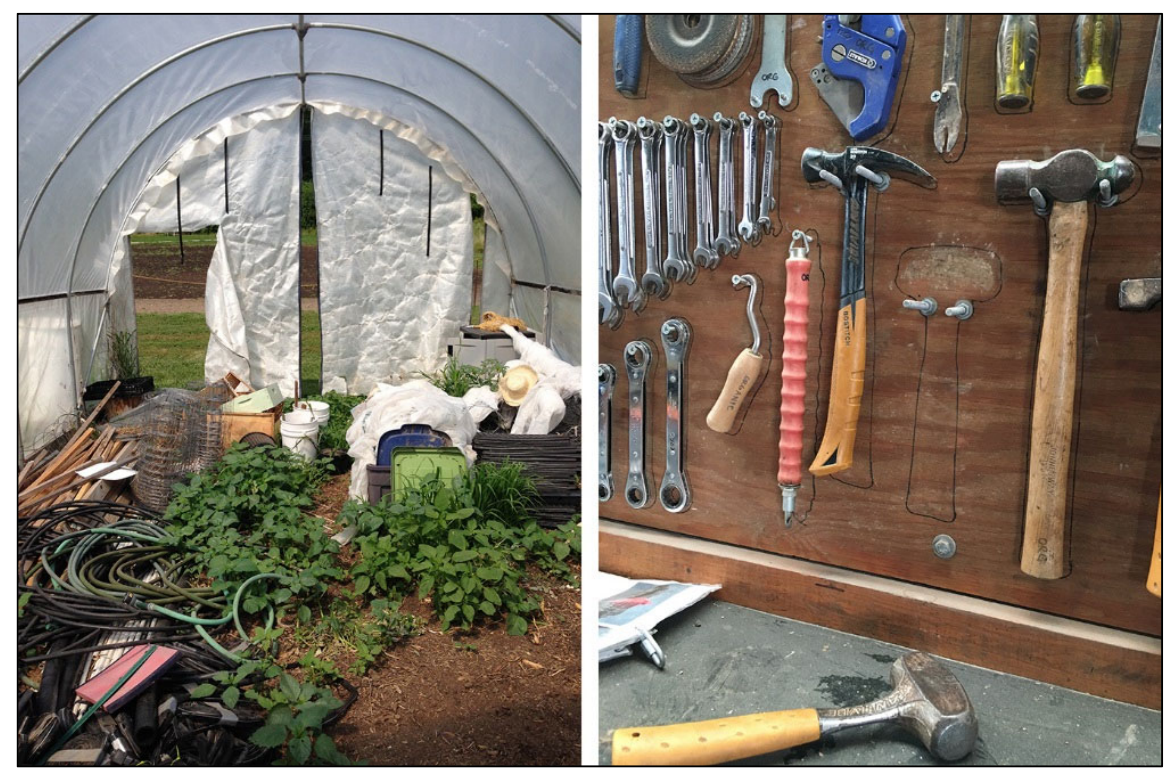


all up here. If you ever need something . . you know it's going to be here. There are no random toolsheds around" (F8). A faculty advisor elaborated on the challenge of dispersed storage spaces, saying, "If we don't have the space to store, then you put a little of it here and a little of it there, and students have to chase around finding it" (F1). Similarly, a student manager described the challenge with offsite equipment or tools, stating,

The more we can build up our own arsenal of tools here rather than borrowing from the botanical gardens, the better. It takes time to go down to the botanical gardens, get a wheelbarrow, come back up, realize you've forgotten to get a pitchfork and then go back down and up. (F5)

The second most important benefit of storage at the farm hub was instating processes for keeping equipment and tools well-organized and cared for (Figure 3). This was paramount to operating efficiently and maintaining high-quality equipment and tools. O ne director noted, "When you've got this many different users, it has to be super clear, so the motto here is like the ship captain's motto, 'a place for everything, and everything in its place'" (F9). Finally, storage facilities that were placed at farm hubs also created social value. In general, site designs will often place storage facilities on the edge of the property, proximate to roadways, or somewhere hidden because it may look messy. But, at successful student farms, storage was located right in the middle of the farm activity (i.e., at the farm hub) and therefore valuable to structuring and promoting meaningful socialization.

D omain 2: $G$ athering A reas

The second domain of successful student farm design is gathering areas (Figure 4). Gathering areas can be defined as designated spaces for specific social functions, which may or may not be incorporated as part of the hub area. All but four of the student farms I visited had at least a casual gathering area under a shade tree or at scattered picnic tables. However, the most beneficial gathering areas provided hybrid spaces that could accommodate small or large groups for various social functions at the farm, such as staff meetings, classes, taking breaks, cooking and eating together, galas, and festivals. Respondents emphasized the critical importance of these intentional gathering areas for community building at the farm, as with successful community gardens (Milburn \& Vail, 2010). For example, one faculty advisor said,

I almost think that sense of place and space is more important than the fields in some way, because so many students come to it for the social community. Y ou need to create that space to foster that community. (F1)

Thriving multifunctional gathering areas tend to include the following features: cover from sun and rain, seating, flat spaces for tables or chairs, and easy access from within the farm. The gathering spaces were entirely either open-air, inside a structure, or more often, a combination of both. Larger farms tended to have two to

Figure 4. Indoor Primary Gathering Area at Farm Hub (Left); Outdoor Event-Sized Gathering Area (M iddle); Outdoor Primary Gathering Area (Right)

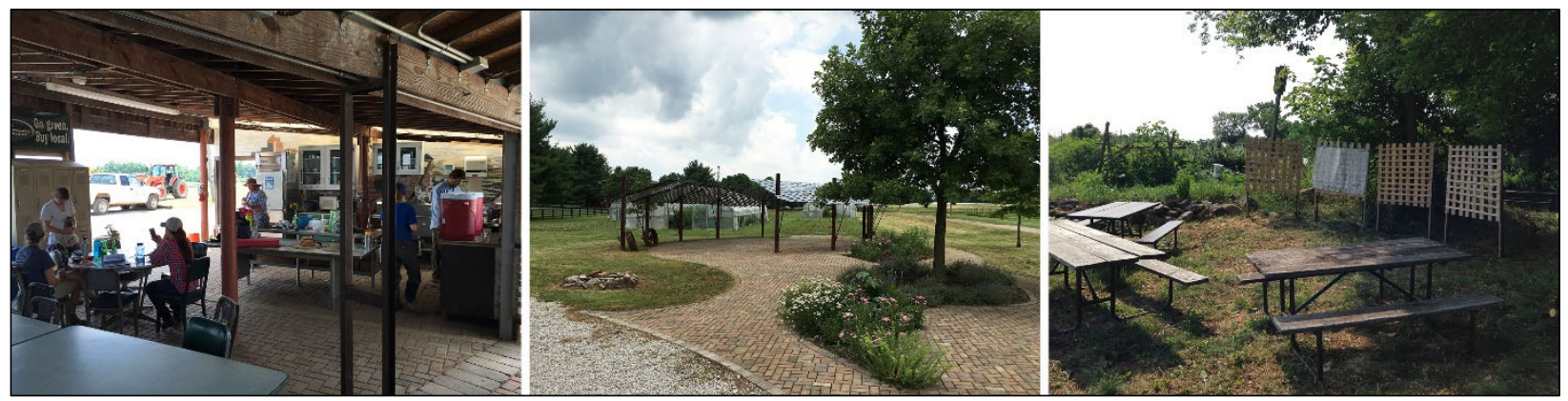


three separate gathering areas that accommodated different sized groups, with the primary gathering area that served daily social functions being combined with the farm hub. This was important to streamline and centralize operational aspects of farm work with community, academic, and administrative facets. Interestingly, the primary gathering areas were not only found to be valuable for farm staff and students but were also found to enhance the volunteer experience. $O$ ne student manager said,

You want their experience to be positive so they come back, so I think it's important to have easily identifiable gathering spaces or places where you know you can get into the shade. (F5)

D omain 3: A ttractions

The third domain of successful student farm design is attractions. Attractions can be defined as unique, artistic, or beautiful features or demonstration spaces that draw people to the site. Attractions tend to be intentionally designed and constructed to serve this purpose. D rawing people to the site using attractions is important to build farm awareness and community outreach. For example, at on-campus student farms, attracting people to the site is important for gathering student interest in sustainable food systems projects, as well as for showing farming strategies to laypeople. However, at off-campus student farms, attracting CSA members to the site is important for grower-to-consumer dialogue and engaging members in the farm experience.

Effective attractions tended to be one of three types: entryways and edges, ornamental and demonstration plantings, and farm craft (see Figure 5). Entryways that were designed as a point of emphasis differentiated the student farm from the surrounding landscape and attracted visitors. Strategies tended to include gates, archways, ornamental plantings, fencing, and signs. Similarly, site edges along visible corridors, such as arterial roads or trails that were well-maintained or intentionally planted, appealed to both passersby and the university administration. For example, campus grounds management lauded student farms that had edge spaces under production or planted with ornamentals because they looked "prettier and better" than previously being overgrown with other vegetation (F10).

Ornamental and demonstration plantings were used to attract and interest people at the farm. These plantings tended to take the form of rain gardens, entryway plantings, U-pick flowers, or pollinator gardens or pods. O ne farm manager said,

Figure 5. Types of Attractions: Entryways and Edges (left), Ornamental Demonstration Planting (Middle), Farm Craft (Right)

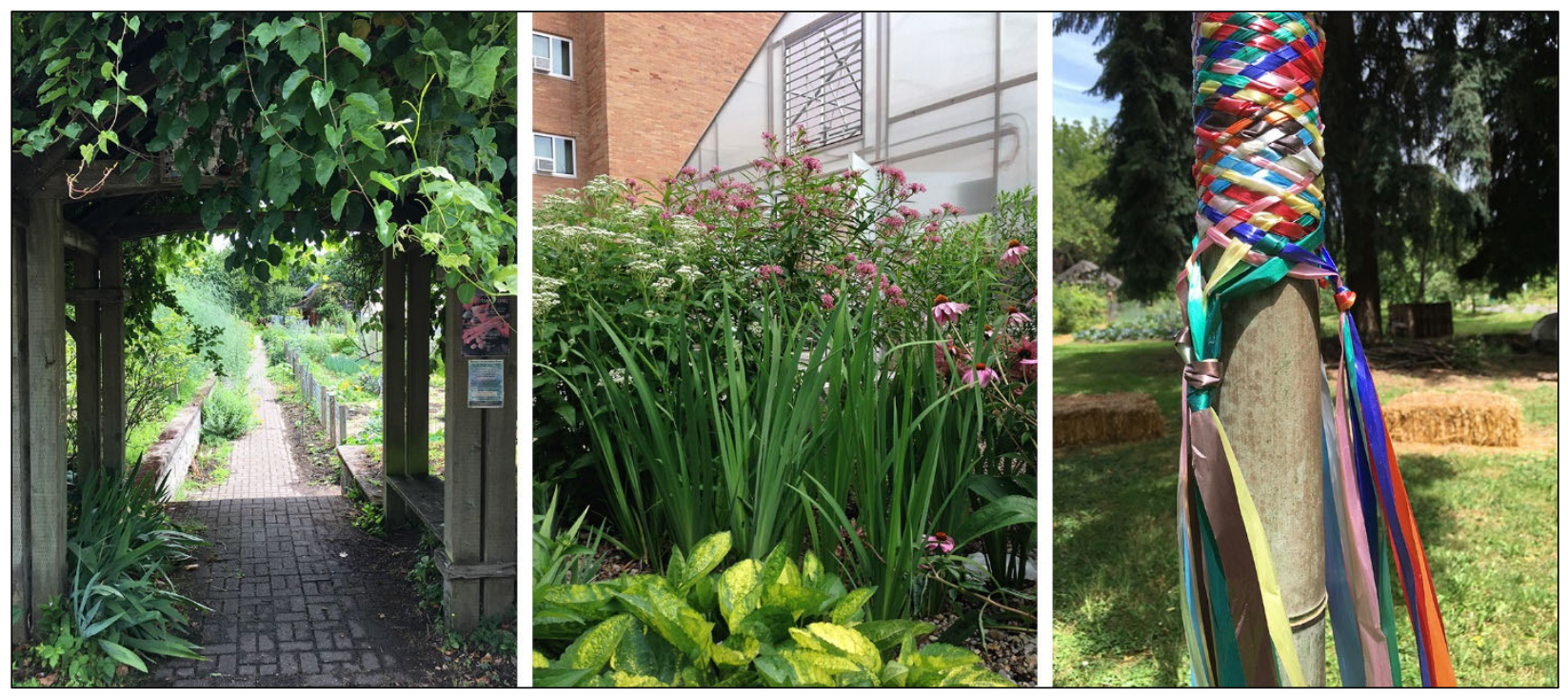


I think, in general, flowers really do add to the space. We have flowers in our U-pick field out there. Just those pops of color, I think that's a draw - to go out into the Upick field and see the flowers. We have the flower gardens here [at the farm hub] and it's a communal space, so people are drawn to it. ... People are drawn to it for the picturesque beauty of it. (F9)

Finally, the inclusion of craft and artistry at the farm was evident in items like sculpture, repurposed planters, handmade bee boxes, and painted signs to provide interesting, unexpected artistic elements to view for staff and visitors. This farm craft was beneficial to create a unique farm character. O ne student manager said that, "I think a good organic farm needs a little quirk here and there just to keep it lighthearted" (F4). High-quality building methods and materials ensured longevity, especially outdoors.

Collectively, these attractions contribute to making a memorable place and forging a strong farm identity. However, when attractions were not supported by farm priorities, these spaces and features were not maintained to the same level of care and aesthetic as other farm spaces, and as a result often became overgrown or dilapidated. Similarly, signage was an element highly valued by farms for building awareness and site wayfinding (see Figure 6). However, handcrafted signs were frequently sloppy or completely faded (Figure 6). High-quality craft and routine maintenance are essential for attractions and signage to sustain their purpose and value.

\section{D omain 4: Student Projects}

The fourth domain of successful student farm design is student projects (see Figure 7). Student projects can be defined as student research plots, experimentation spaces, and independent projects or studies. Student projects tended to either be permanent projects or spaces that evolved yearly and included projects such as food forests (or other forms of polyculture or edible perennial areas), staff personal plots, herb spirals, aquaponic systems, and architecture-related projects.

Respondents emphasized that student projects are fundamental to being a student farm and promoting innovation, hands-on learning, and individual ownership. For example, one staff member said, "I really think that once they get up there and have worked a little, the students start an emotional attachment to the space, and what the process is" (F5).

Meanwhile, respondents also identified challenges with the coordination, quality, and maintenance of student projects (Figure 7). For example, a student's accountability to complete a project can be tenuous and lead to piecemeal work. In addition, student-driven work may not be required to follow professional standards, especially when exploring innovative techniques or materials. This

Figure 6. Professional Signage (Left and Center Left); Dilapidated Handmade Signage (Right and Center Right)
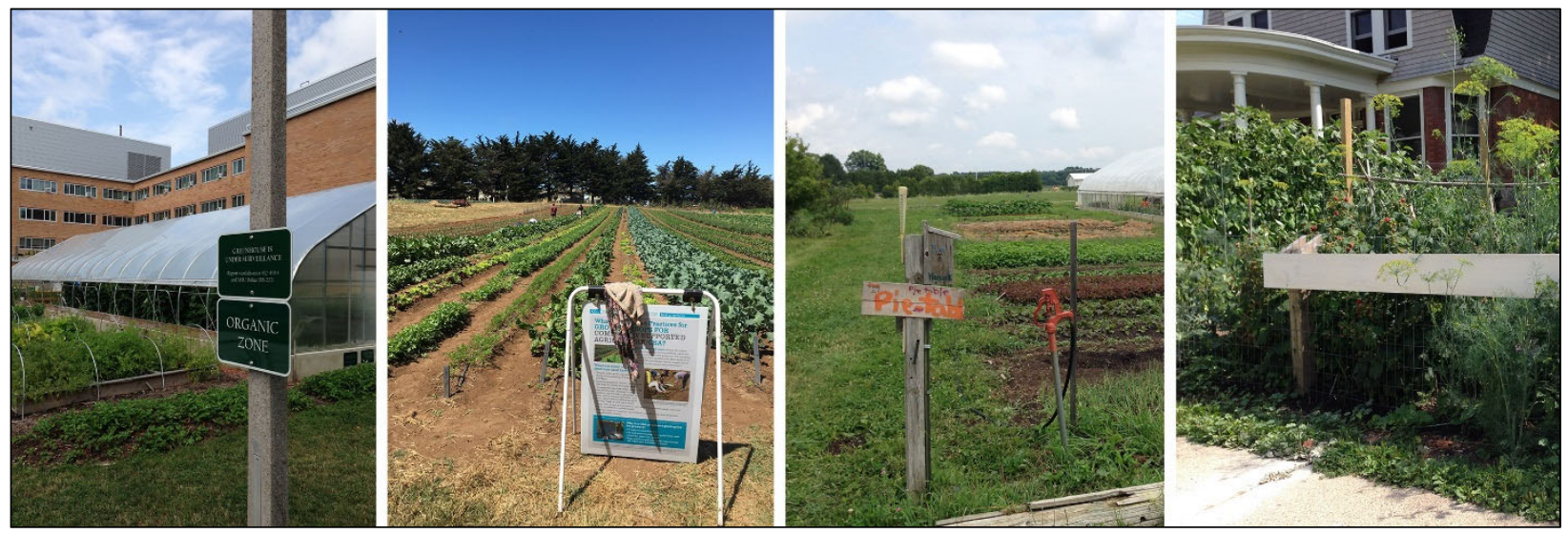
Figure 7. Compost Experiment Plots (Left) and Farm Hub Building Design Project (Center Left); Unmaintained Herb Spiral (Center Right) and Overgrown Polyculture Project (Right)
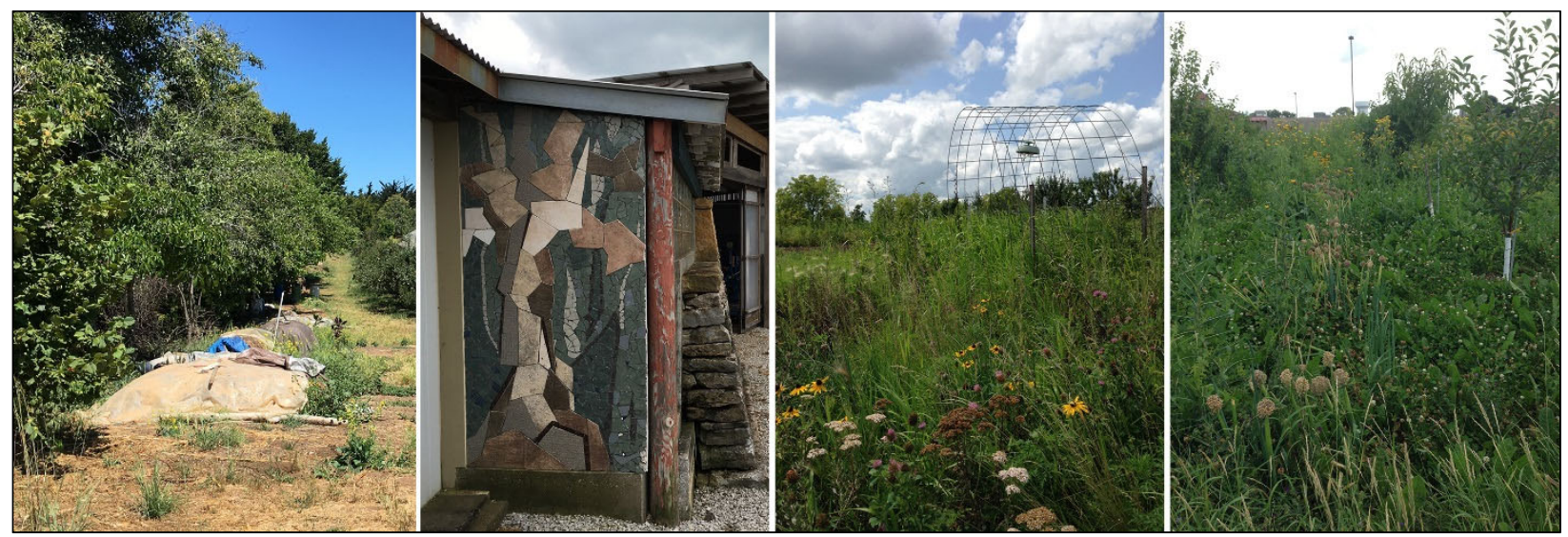

can lead to farm features or spaces that are underutilized or defective. O ne farm director noted that,

They say they'll come back and finish 'em, and then they never do. That would be one thing that I would caution people, when you start doing these projects, is that this isn't just a hypothetical kind of student project. This is actually a functioning farm. (F9)

Student turnover also complicates long-term care of or interest in student projects, which can create neglected spaces over time. For example, a new technology or farming method explored by a student may result in physical changes to the farm that become obsolete or may have been championed only by a cohort of students during a particular period. O ne faculty advisor described such a challenge with a food forest area, saying, "I never show it to anybody because it looks like hell because it's an example of a really interesting idea that needs a lot of attention in the early stages" (F1).

Certainly, having a clear administrative protocol to approve and advise student projects is necessary to manage effective short- and long-term changes to the farm site. Beyond administrative strategies, successful farms benefit from applying two physical strategies to balance the benefits and challenges of student projects. First, they allocate specific areas to place student projects that have fewer appearance expectations. For example, one farm embedded staff personal plots within a food forest area, where aesthetics were already more flexible. Second, student projects may be placed in areas with lower visibility, like back edges or transitions away from key pathways and entrances. For example, one farm placed student compost research plots in a transitional space between two production zones that was lined with a hedgerow that provided a visual buffer (F12). Finally, simply keeping student projects well-maintained by using cues-to-care and signage to "frame" the project's purpose can optimize the impact of the project.

D omain 5: Compost A reas

The fifth domain of successful student farm design is compost stations or areas. Every farm site studied discussed design considerations for compost because "pretty much what you do every day uses compost. Either you're putting into it or taking out of it" (Student, F10). Student farms tend to generate more biomass than their compost areas can process. Therefore, the successful design of compost areas includes three recommendations: truck access, convenient placement, and aesthetics. First, placing compost areas to accommodate the circulation of large trucks is essential for easily removing or delivering material. Second, compost areas that are convenient to cultivation areas where biomass is produced are a benefit because "the shorter the distance that you have to take, the easier it is" (Student, F10). Finally, the aesthetics of 
the compost structures and bins is important for public and campus acceptance.

Besides animals, compost spaces elicited some of the most impassioned design conflicts at the farms studied. Composting areas at farms located on-campus or the campus edge were scrutinized and considered to be an "ongoing issue" (Student, F8). Strategies employed in these cases included using clearly delineated piles, high-quality construction materials and craft, and routine care of the area to "keep it tidy" (see Figure 8). For example, several farms cautioned against using shipping pallets, a common reused material for compost bins. O ne faculty director noted, "As soon as we removed like 75 percent of the pallets we had no more issues" (F4). Finally, in highly-visible locations farms had to convince campus planning and administration that it wouldn't smell, attract rodents or other pests, and that its on-farm location was essential for farm functionality.

\section{D omain 6: Reflective Places}

The sixth domain of successful student farm design is reflective places. Reflective places are intimate spaces or features for individuals or very small groups to have conversations, make observations, or seek solitude. These places are separate from the gathering areas that are best associated with the farm hub to accommodate larger group functions. Respondents emphasized the value of these smaller sites for respite to the physical labor involved at the farms. However, interestingly, these places were discussed most often as beneficial for stress reduction, mental restoration, and interpersonal connections. For example, one student stated, "Being out here is so nice, and it really takes you away from the stress of campus, because it does feel like you're going somewhere else" (F8). Likewise, one farm staff member described why students are drawn to the farm, saying,

I don't even think the free food is the main driver.... I think honestly a lot of them just like to come out, hang out, not stare at their cell phones for two hours, but actually talk and engage with one another and get their hands dirty. I think that's the biggest thing. (F5)

Figure 8. Compost Areas in Different Settings: Central Campus (Left), Campus Edge (Center), and Off-Campus (Right)
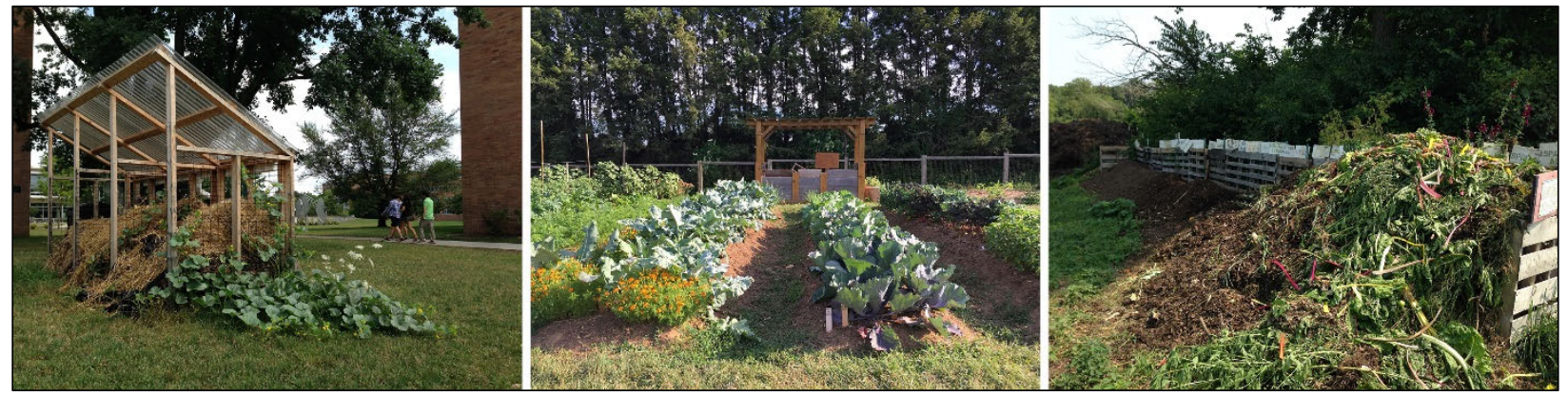

Figure 9. Reflective Seating at Pig Project (Left), Farm Vista (Center), and Memorial Grove (Right)
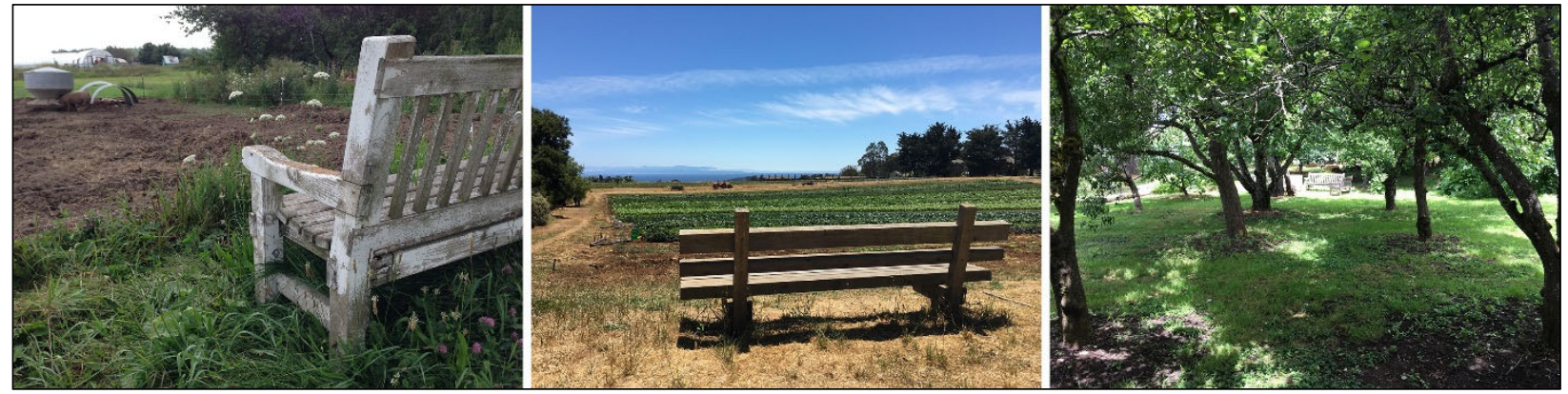
These reflective places tended to consist of seating in the farm site designed to observe production spaces or picturesque views, or to take refuge in the shade (see Figure 9). A farm manager described one of these favorite places, sharing that, "There's this overlook that goes down into the woods. ... It's a very peaceful, quiet spot, nobody goes back there. But you can look off into the woods and just reflect for a second" (F8). Another farm staff member said that, "Then [there's] the ocean view fields [that are important.] There is a particular spot on the farm that you can see Monterey Bay and it's just glorious and shining. I call it the money shot. I mean, it's really impactful" (F12).

Being immersed in a dense production field was also described as a reflective experience. For example, one student said, "in the middle of the field if you're down on your hands and knees weeding, and you can't see anything around you and it just feels like you're enclosed by the farm, it's nice" (F5). Another farm staff member described the importance of these small design movements, saying,

But then also [important are] those little secret spaces that are where you feel in close, cradled by the environment, and it makes you look at the details more closely. Like inside the bamboo- there is one little place when you go inside of it, it's like you get into another world. (F12)

The reflective places tended to be a combination of intentionally placed features as part of the site design along with an organic evolution of meaning and use for farm users. Although the character and experience of these features should be expected to change through time, the places should be formally included in farm master plans to prioritize the benefits of nearby nature and reflection that the farm provides for student health and well-being.

\section{Conclusions}

This study contributes new perspectives for developing successful college and university student farms by broadening considerations to the physical and spatial aspects of a farm in the university setting. The considerations presented will not equate to success in and of themselves. Successful student farm site selection and design also depend on the integrated systems at play both on and off the farm, for example, staffing, funding, marketing, curricula, water, and other resource access, in addition to design considerations for the intended production systems. This study's findings add another layer of understanding to apply upfront as student farm projects develop master plans. Although the site selection and design considerations could be comprehensively constructed all at the start of a new project, the reality is that a site's design and its character unfold over time. Student farm scholars (Ratasky et al., 2015; Sayre \& Clark, 2011) recommend that starting small and evolving over time allows for purposeful growth and sustained programming.

When undergoing site selection as part of farm planning, the findings highlight the need to expand site assessment to include spatial factors in addition to the site's biophysical conditions, including sun exposure, soil quality and toxicity, and water. The findings outline how accessibility, appearance expectations, and visibility conditions vary across farms in different campus locations, which, in turn, affect farm productivity and user engagement. As student farm projects assess potential sites based on these three considerations, they will be challenged by tradeoffs. For example, an on-campus site may tend to favor better people-related accessibility, while an off-campus site may favor better facilities-related accessibility. Or, while maintenance for aesthetics is necessary at any site location, on-campus sites are expected to have an appearance that blends with the more ornamental, constructed surroundings. This study provides patterns of these tradeoffs that should be discussed and used to build a rationale for acquiring a site that best enables farm goals, rather than choosing a site for which it was easier to receive campus planning approval. The student farms studied that initially acquired sites that were not the best size, configuration, or location experienced enough challenges that the projects failed or moved. Advocating for the most appropriate site upfront allows the farm to sustainably invest money, time, and 
Journal of Agriculture, Food Systems, and Community Development

ISSN: 2152-0801 online

https:/ / www.foodsystemsjournal.org

Table 2. Summary of Physical Considerations for Six Domains of Student Farm Site Design

\begin{tabular}{|c|c|c|}
\hline 1. Farm hub & 2. Gathering Areas & 3. Attractions \\
\hline \multirow{2}{*}{$\begin{array}{l}\text { "Center" of site organization: Create } \\
\text { hierarchy of spaces, with those } \\
\text { needing most attention near farm } \\
\text { hub; create site legibility with clearly } \\
\text { delineated areas. } \\
\text { Starting point for farm flow: Connect } \\
\text { spaces starting from farm hub; } \\
\text { sequence circulation from dirty to } \\
\text { clean. }\end{array}$} & $\begin{array}{l}\text { Multifunctional: Design space(s) for } \\
\text { small to large groups to serve a } \\
\text { variety of educational and social } \\
\text { functions, such as class, seminars, } \\
\text { meetings, galas, lunch breakroom. }\end{array}$ & $\begin{array}{l}\text { Placemaking: Incorporate attractions to } \\
\text { create strong farm identity; need to } \\
\text { keep well maintained to remain } \\
\text { impactful. }\end{array}$ \\
\hline & $\begin{array}{l}\text { Location: Integrate at or nearby farm } \\
\text { hub for community building and farm } \\
\text { engagement. }\end{array}$ & $\begin{array}{l}\text { Entryways and edges: Design points of } \\
\text { emphasis or corridors to add appeal. } \\
\text { Strategies such as, gates, arbors, } \\
\text { ornamental plantings, fences, signs. }\end{array}$ \\
\hline $\begin{array}{l}\text { Clean. } \\
\text { Administration activities: Create } \\
\text { communication center with task } \\
\text { board, office, meeting area, and } \\
\text { visitor entry point. }\end{array}$ & \multirow[t]{2}{*}{$\begin{array}{l}\text { Features: Include shade or cover, } \\
\text { seating, flat space for tables and } \\
\text { events, kitchen. }\end{array}$} & $\begin{array}{l}\text { Ornamental or demonstration } \\
\text { plantings: Include plantings to interest } \\
\text { visitors in farm sites and practices. } \\
\text { Strategies such as rain gardens, green } \\
\text { roof gardens, themed raised beds, U- } \\
\text { pick areas, pollinator gardens. }\end{array}$ \\
\hline $\begin{array}{l}\text { Storage: incorporate Permanent, } \\
\text { centralized structure for equipment, } \\
\text { materials, and staff lockers. }\end{array}$ & & $\begin{array}{l}\text { Farm craft: Create artistry with farm } \\
\text { materials, signs, sculptures, etc., to } \\
\text { build farm character. }\end{array}$ \\
\hline 4. Student Projects & 5. Compost & 6. Reflective Places \\
\hline \multirow{2}{*}{$\begin{array}{l}\text { Ownership: Promote student learning } \\
\text { and site ownership by strategically } \\
\text { designing areas for student projects. } \\
\text { Strategies include experimentation } \\
\text { projects, research plots, food forests, } \\
\text { aquaculture. }\end{array}$} & $\begin{array}{l}\text { Location: Place to accommodate truck } \\
\text { circulation and for convenient access } \\
\text { to large production spaces }\end{array}$ & \multirow{2}{*}{$\begin{array}{l}\text { Small social spaces: Design intimate } \\
\text { spaces for individuals to small groups } \\
\text { for conversation, observation, or } \\
\text { solitude. } \\
\text { Location: Disperse throughout farm } \\
\text { site. }\end{array}$} \\
\hline & \multirow{3}{*}{$\begin{array}{l}\text { Aesthetics: Keep it tidy; align materials } \\
\text { and appearance to surrounding land- } \\
\text { scape; caution on re-use of shipping } \\
\text { pallets. }\end{array}$} & \\
\hline $\begin{array}{l}\text { Location: Allocate less visible areas } \\
\text { where appearance is more flexible. }\end{array}$ & & \multirow[t]{2}{*}{$\begin{array}{l}\text { Features: Include seating, views, sense } \\
\text { of enclosure, shade. }\end{array}$} \\
\hline $\begin{array}{l}\text { Aesthetics: Keep well maintained with } \\
\text { signage about project's intent. }\end{array}$ & & \\
\hline
\end{tabular}

student resources, as well as set the stage for successful onsite design.

Table 2 summarizes the findings for the six identified domains of site design. The findings provide an overarching framework for developing site plan layouts, organization of spaces, and detailed design features to foster success. An overarching theme that emerged is the imperative that spaces not only be designed for production and teaching needs, but also for the social functions and farm identity that influence educational experiences, student learning, and community engagement. This mirrors site design recommendations for urban agriculture projects in community or other contexts (G ocova, n.d.; Milburn \& Vail, 2010; Philips, 2013), but has not been thoroughly articulated in the university student farm scholarship. The well-developed farm hub, especially with gathering areas, tends to be one of the key domains for successful farm functionality. Most importantly, centralized storage, administration, and social areas allow for the integration of the activities associated with operations, teaching, and community building. Attractions and experimentation areas are important for gaining student interest and ownership on the farm, as well as designing spaces for demonstration and outreach. Finally, reflective places benefit student discussion, health, and well-being and foster a deeper connection to the farm.

F uture D irections

Because this study is an initial exploration of physical design, more research is needed to illustrate exemplary college and university student farm cases that apply these site selection and design principles. A future study could develop a student farm typology to show how the six site domains are designed at student farms in different campus 
locations. Or, in contrast, further investigation of the physical characteristics on farms that have failed may uncover strategies that should be avoided. In addition, further research could explore connections between site design features and student learning outcomes and experiential impacts. For example, this study's data revealed a deep connection between student farms spaces and user experience being in nature. To this end, a future study could investigate the human health and wellbeing benefits of student farms for campus environments.

In closing, this study made evident the breadth of benefits that student farm physical spaces have on students beyond building disciplinary knowledge and skills. One farm manager described what happens at a student farm,

It's just like life comes out. And even if you're not trying to, it happens. And there's a lot of conversations, a lot of in-the-field mentoring, a lot of life. Just life stuff. When I look for higher up staff, I look for people who could be a good mentor, because that's what ends up happening in the field. (F8)

The physical site design, in part, allows these experiences to emerge. This investigation summarizes considerations for how to successfully select and design college and university student farm sites to be valuable, lasting places in the campus environment.

\section{Acknowledgments}

I would like to thank Maggie Crowley for help with data collection, and the students, faculty, and staff of the 19 student farm projects for their time and the vital information and insight they shared for this research.

\section{References}

Ashling, J., Tchida, C., Markhart, A., \& Porter, P. (2007). O rigin of cornercopia, the University of Minnesota student organic farm. Journal of $\mathrm{H}$ unger \& E nvironmental N utrition, 1(2), 27-42. https:/ / doi.org/ 10.1300/ J477v01n02 03

Biernbaum, J. A. (2006). Student and new farmer education to support the growth of organic farming. Crop Management, 5(1). https:/ / dl.sciencesocieties.org/ publications/ cm/ index

Biernbaum, J. A., Ngouajio, M., \& Thorp, L. (2006). Development of a year-round student organic farm and organic farming curriculum at Michigan State University. H ortT echnology, 16(3), 432-436. Retrieved from http:/ / horttech.ashspublications.org/ content/ 16/ 3/ 432.abstract?sid=b47db44d-8baf-4703-b68a-a5072e89eee8

Boyatzis, R. E. (1998). Transforming Q ualitative Information: Thematic analysis and code development. Thousand O aks, CA: Sage.

Carlson, S. (2008, March 28). The Farmer in the Q uad. The C hronide of H igher E ducation. Retrieved from http:/ / www.chronicle.com/ article/ The-Farmer-in-the-Quad/ 20394

Clark, S. (2014). Resource-use and partial-budget analysis of a transition to reduced-input and organic practices and direct marketing: A student-farm case study. Journal of A griculture, F ood Systems, and C ommunity D evelopment, 4(2), 113130. https:/ / doi.org/ 10.5304/ jafscd.2014.042.005

Creswell, J. W. (2014). Research D esign: Q ualitative, Q uantitative and Mix ed M ethods A pproaches (4th edition). Thousand Oaks: SAGE Publications, Inc.

D eming, M. E., \& Swaffield, S. (2011). L andscape A rchitectural Research: Inquiry, Strategy, D esign (1 edition). Hoboken, NJ: Wiley.

Francis, M., \& Griffith, L. (2011). The meaning and design of farmers' markets as public space an issue-based case study. L andscape Journal, 30(2), 261-279. https:/ / doi.org/ 10.3368/ lj.30.2.261

Glaser, B. G., \& Strauss, A. L. (1967). The D iscovery of G rounded Theory: Strategies for qualitative research. New Y ork, NY: Aldine de $\mathrm{G}$ ruyter.

Gocova, A. (n.d.). U rban A griaulture G arden G uide: Manual for starting and designing urban agriculture projects. Vancouver Board of Parks and Recreation and City of Vancouver. Retrieved from https:/ vancouver.ca/ files/cov/ urban-agriculturegarden-guide.pdf

Hyslop, T. (2015). E x ploring Student F arms: A look at student farms at ten universities across the united states. Rutgers University. Retrieved from http:/ / agriurban.rutgers.edu/ D ocuments/ Student\%20Farm\%20Research.pdf 
LaCharite, K. (2016). Re-visioning agriculture in higher education: The role of campus agriculture initiatives in sustainability education. A griculture and $\mathrm{H}$ uman V alues, 33(3), 521-535. https:/ / doi.org/ 10.1007/ s10460-015-9619-6

Lawson, L. J. (2005). City Bountiful: A Century of C ommunity $G$ ardening in A merica. Berkeley: University of Califormia Press.

Leis, A., Whittington, M. S., Bennett, M., \& Kleinhenz, M. (2011). Student farms at United States colleges and universities: Insights gained from a survey of the farm managers. N A CTA Journal, 55(1), 9-15. Retrieved from https:/ / www.nactateachers.org/ index.php/ vol-55-num-1-mar-2011-sp-1003999532/ 502-student-farms-at-unitedstates-colleges-and-universities-insights-gained-from-a-survey-of-the-farm-managers

Markhart, A. H. (2006). O rganic educational opportunities at the University of Minnesota: The role of a student-run organic farm. H ortT echnology, 16(3), 443-445. Retrieved from http:/ / horttech.ashspublications.org/ content/ 16/3/ 443.abstract?sid=fa89392b-19d5-472d-ad08-b3e9b7586659

Milburn, L.-A. S., \& Vail, B. A. (2010). Sowing the seeds of success cultivating a future for community gardens. L andscape Journal, 29(1), 71-89. https:// doi.org/ 10.3368/ lj.29.1.71

Nassauer, J. I. (1995). Messy ecosystems, orderly frames. L andscape Journal, 14(2), 161-170. https:/ / doi.org/ 10.3368/ lj.14.2.161

Parr, D. M., \& Horn, M. V. (2006). D evelopment of organic and sustainable agricultural education at the University of California, D avis: A closer look at practice and theory. H ortT echnology, 16(3), 426-431. Retrieved from http:/ / horttech.ashspublications.org/ content/ 16/3/ 426.abstract?sid=77a36c42-28fc-4419-86b7-b58102a43ce3

Parr, D. M., \& Trexler, C. J. (2011). Students' experiential learning and use of student farms in sustainable agriculture education. Journal of $N$ atural Resources and L ife Sciences E ducation, 40(1), 172-180. https:// doi.org/ 10.4195/jnrlse.2009.0047u

Philips, A. (2013). D esigning U rban A griaulture: A C omplete G uide to the Planning, D esign, C onstruction, Maintenanœe and $M$ anagement of $E$ dible $L$ andscapes (1st edition). Hoboken, New Jersey: Wiley.

Ratasky, S., Schroeder-Moreno, M., Jayaratne, J., Bradley, L. K., G rossman, J., \& Orr, D . (2015). Identifying Key Characteristics for Student Farm Successes through a National D elphi Study. N A CT A Journal, 59(2), 96-103. Retrieved from https:/ / www.nactateachers.org/ index.php/ volume-59-number-2-june-2015/ 2293-identifying-keycharacteristics-for-student-farm-successes-through-a-national-delphi-study

Sayre, L., \& Clark, S. (Eds.). (2011). Fields of L earning: The Student Farm M ovement in N orth A merica. Lexington: University Press of Kentucky.

Sustainable Agriculture Education Association. (2016, O ctober 11). Student Farms \& G ardens. Retrieved August 11, 2017, from http:// www.sustainableaged.org/ projects/ student-farms/ 